\title{
The Effect of Impulsivity vs. Reflectivity on Reading Comprehension of Iranian EFL Learners
}

\author{
Somayeh Shabani ${ }^{1 *}$, Mohammad Ramazani ${ }^{2}$, Iman Alipoor ${ }^{3}$ \\ ${ }^{1}$ Tabriz Azad University, Iran \\ ${ }^{2}$ Payame Noor University, Iran \\ ${ }^{3}$ Department of English, Torbat-e-Heydarieh Azad University, Iran
}

Corresponding author: Somayeh Shabani, E-mail: Mahsashabani@Yahoo.com

\section{ARTICLE INFO \\ Article history \\ Received: June 22, 2017 \\ Accepted: July 30, 2017 \\ Published: July 31, 2017 \\ Volume: 5 Issue: 3}

Conflicts of interest: None

Funding: None

\begin{abstract}
In recent years attention has been accorded to language learners' affective factors and learning styles. Two of the significant learning styles are impulsivity and reflectivity which have not been studied as much as other styles such as introversion and extroversion. This study endeavored to find out whether or not impulsivity and reflectivity have any effect on reading comprehension of Iranian English as a Foreign Language (EFL) learners. Seventy two language learners were selected from 4 intact classes out of 112 learners. Nelson proficiency test was given to the participants as homogeneity test. Next, Barrat's (1995) impulsiveness questionnaire was given to the participants. Based on the results of the questionnaire, the participants formed 3 different groups, i.e., a reflective group $(n=25)$, impulsive group $(n=25)$ and a control group $(n=22)$. The control group consisted of less impulsive and less reflective learners based on Barrat's scale. An IELTS reading test (general module) was administered to the participants. Based on the results of independent samples t-test, it was found that impulsivity and reflectivity do not have any effect on reading comprehension of Iranian EFL learners. Pedagogical implications are discussed.
\end{abstract}

Key words: Impulsivity, Reflectivity, Reading Comprehension, Iranian EFL Learners

\section{INTRODUCTION}

The role of reading comprehension in academic success or failure of language learners is undeniable so much that many studies have focused on how to enhance reading texts in order to increase intake of information (Han, Park, \& Combs, 2008). On the other hand, recent research in the field has revealed that certain features of the language learners can also affect language learning. One of these features is language learners' learning styles (Wang, Wang, \& Huang, 2008). Oxford (1991) noted that an individual learners' style determines the type of strategy he or she uses to learn; therefore, it should have an effect on learning languages. In the same vein, Kolb and Kolb (2005) pointed out that determining ones learning style can indicate what appropriate channel should be opted to conduct classes. Therefore, it seems significant to study learners' learning styles and their effect on reading comprehension.

$\mathrm{Xu}$ (2011) who presented taxonomy of learning styles noted that among learning styles personality learning styles are of the most significant effect on learning. Personality learning styles are usually discussed under two main headings, i.e., reflectivity and impulsivity. Reflective learners are those who seek accuracy and fluency, whereas, impulsive learner prefer to learn more thoroughly rather than more precisely. The former groups avoid making mistakes, while the latter might be more open to making mistakes.
The question left open is how impulsivity and reflectivity can affect reading comprehension of Iranian EFL learners. To answer the question, this study was conducted.

Recent years of research in applied linguistics have been named era of 'Affect' according to Zoghi (2012). Focus has been accorded to learners' psychological traits and barriers such as motivation, anxiety, and style, yet a wide gap is felt between research and what is practically been conducted in language classes. In the context of Iran, language learners are never discriminated based on their learning styles into various classes. Classroom activities do not have psychological trait-based orientations and, regardless of the course, material are fixed in format with slight variations in type of tasks composition All this is happening contrary to research findings which show in most cases that learners' preferred way of learning can affect the outcome of courses. This indicated the need for understanding the effect of learning styles on language learning. As for reading comprehension, research on the effect of learning styles and reading is scant; therefore, this study was conducted.

\section{Purpose of the Study}

The main purpose of the study is to find out if learning styles have any effect on reading comprehension of Iranian EFL learners. To do so, two of the significant personal 
learning styles, as stated by $\mathrm{Xu}$ (2011), i.e., impulsivity and reflectivity were opted. Additionally, this study is aimed at comparing the effect of these two learning styles on reading comprehension of Iranian EFL learners.

\section{Research Questions}

1. Does impulsivity have any effect on reading comprehension of Iranian EFL learners?

2. Does reflectivity have any effect on reading comprehension of Iranian EFL learners?

3. If the answers to research questions 1 and 2 are yes, which learning styles, i.e., impulsivity vs. reflectivity have more effect on reading comprehension of Iranian EFL learners?

\section{Significance of the Study}

The gap between research and language classes can be filled with reviewing up-to-date and innovative findings in the field. Admittedly, one aspect of this innovation is understanding learning styles. Lazanov (1979) believed that language teachers should view their learners as 'whole person' (p.67). He elaborated on this issue and noted that language teachers should understand their learners from various perspectives: their feelings, barriers to learning, background, etc. One aspect of every learner is his/her learning style. Therefore, it is significant to know learners' preference in learning and this paper can clarify this issue.

Material designers can use the discussion presented in this paper to design more purposeful materials that suit the needs of their learners based on their learning styles. Language teachers can give input to the learners in an interactive manner and consider their styles in the type of input they give to the learners. Language learners can acknowledge and understand their learning style. Based on this understanding they can use adjust their learning.

\section{REVIEW OF THE LITERATURE}

\section{An Overview of Learning Styles}

According to some psychologists more than 70 different learning styles exist. However, not all these styles are relevant to learning languages, since language learning has certain characteristics which are unique to language. Xu (2011) categorized learning styles into 3 main categories, i.e., perceptual, cognitive and personality learning styles and discussed those which were more related to language learning.

\section{Perceptual Learning Styles}

Perceptual (sensory learning styles) are related to one's senses. Although the number of studies dealing with these styles are less than those conducted on cognitive styles (Wang, Wang \& Huang, 2008), there are studies that have discussed their effect on language learning. Reid (1995) asserted that visual and auditory learning styles are among the most significant perceptual learning styles. Gilakjani (2011) assumed that language teaching methods that have interactive forms are more suitable for kinesthetic, visual and auditory learners. Such interaction, however, should be based on learners' learning styles. Therefore, role models in audio lingual method can aid visual learners. On the other hand, total physical approach can be suitable for kinesthetic learners and listening activities may suit auditory learners. It should be mentioned that all language teaching methods might have activities that foster visual, auditory or kinesthetic learning; however, language teachers should be aware of their learners' styles to select the teaching methods (Cohen, 2003).

\section{Cognitive Learning Styles}

$\mathrm{Xu}$ (2011) believed that the most significant group in this taxonomy is field dependence vs. field independence. Field dependent learners have and analytical view and look at the depth of an issue by searching for constituent sections, whereas field independent learners have a more global view at reality and attempt to view things as a whole. LittleWood (2002) suggest integrating hypermedia to language education for field independent learners, since they go deep into details of, for example, a text. Therefore, technology-oriented aids such as hypertext can aid them. It is also suggested by Nation (2001) to guide global learners on using scanning techniques while reading. This technique can help them have an in-depth look at the text, because they are already good at techniques such as skimming and look at the text as a whole.

\section{Personality Learning Styles}

Introversion vs. extroversion and impulsivity vs. reflectivity are among the most significant groups in this category. Although literature on learning styles show no method directly based on language learners' learning styles, it has been noticed that there are differences between language learning of introvert and extrovert learners. Most these studies have concluded that extrovert language learners are better learners than introvert ones. On the other hand, impulsivity and reflectivity have been studied in a number of other studies. Rastegar and Safari (2017) who studied the effect of impulsivity and reflectivity on learning English vocabulary through output-based instruction concluded that these personality learning styles do not have any effect on vocabulary learning of Iranian EFL learners.

Hajimohammadi and Mukundan (2011) investigated the effect of learning styles on writing. They measured the effect of self-correction on writing skill of introvert and extrovert Iranian EFL learners. They used 120 Iranian pre-intermediate learners in their study and used Eysenck questionnaire to divide the language learners into introvert and extrovert ones. The results of the study revealed that self-correction is a more effective correction technique for introvert language learners compared to extrovert ones.

Nematpour (2012) investigated learners' autonomy level and its relationship with learning style. They made use of 200 undergraduate students who were studying at university level. They used two questionnaires to conduct this study. One was Perceptual Learning Style Questionnaire, and the 
other one was the Learner Autonomy Questionnaire. The results revealed that visual and auditory learning styles were significantly and positively related to their learner autonomy. However there were no significant differences among males and females regarding language learning style and autonomy level.

\section{METHOD}

\section{Design of the study}

This study is a cross sectional study, and the participants for the study were selected through convenience approach. In addition, the study has a between subject design. Conclusions are made based on observable data; therefore, quantitative methods were used to collect data in this study.

\section{Participants}

Seventy two participants for this study were selected non-randomly through the convenience approach from 4 intact classes $(n=112)$ at intermediate level at a language institute in Tehran. The participants had mixed genders and were all adult EFL learners with at least two years of experience in language learning. Proficiency level was not among the main variables in this study; therefore only intermediate EFL learners were used. Participants were all adult EFL learners. It should also be mentioned that a number of confounding variables exist in this study with regard to the participants such as education, social and economic background.

\section{Instruments}

\section{Nelson language proficiency test}

Nelson test is a language proficiency test designed for homogenizing intermediate EFL learners. The test consists of 50 items and takes 50 minutes to accomplish. The test has repeatedly been reported to be reliable in various studies.

\section{Barrat's impulsivity scale (1995)}

Barrat (1995) impulsiveness questionnaire was used in this study to divide the participants into more impulsive and more reflective learners. The questionnaire is a valid one, and has been repeatedly been used for this purpose (e.g., Rastegar \& Safari, 2017).

\section{IELTS reading test}

An IELTS reading test (general module) was used to measure the participants' ability in answering reading comprehension questions. The test contained 3 reading texts (around 2500 words) accompanied with 40 research questions. The test lasted for 1 hour.

\section{Procedure}

This study was conducted over the period of 2 days. In the first day of the study, consent forms along with Barrat (1995) impulsivity questionnaire and Nelson language proficiency Test were administered. In the second day of the study, IELTS reading test was administered to the participants in order to measure their reading comprehension. The results of all tests were used to find the answer to the research questions.

\section{RESULTS}

\section{Exploratory Data Analysis Results}

In the first phase of the data analysis, distribution of data was checked for all tests.

As can be seen in Table 1, ratios of skewness and kurtosis over their respective standards are within the range of +/- 1.96; therefore' normal distribution of scores was assumed. Next the reliability of the reading test was measured using Cronbach Alpha formula. The results of reliability test for the impulsive group, reflective group and the control group were $\alpha=.79, \alpha=.82$, and $\alpha=.80$ respectively.

Due to normal distribution of scores, the data analysis was continued with parametric tools.

\section{Effect of Impulsivity on Reading Comprehension}

To answer the first research question, "Does impulsivity have any effect on reading comprehension of Iranian EFL learners?" the reading scores of the impulsive group was compared with those of the control group using independent samples t-test.

The impulsive group's mean $(\mathrm{M}=24.4, \mathrm{SD}=3.7)$ is slightly less than the control group's mean $(\mathrm{M}=24.5, \mathrm{SD}=3.5)$ by 0.1 .

As can be seen in Table 2, the results of independent samples t-test $(\mathrm{t}(45)=-0.93, \mathrm{Sig}=.926$ [-2.256-2.0561], indicate that the difference between the control group's mean score and the impulsive group's mean score is not significant; therefore, the first null hypothesis was supported and it can be assumed that impulsivity does not have any effect on reading comprehension of Iranian EFL learners.

\section{Effect of Reflectivity on Reading Comprehension}

To answer the second research question, "Does reflectivity have any effect on reading comprehension of Iranian EFL learners?" independent samples t-test was run between the control group and the reflective group.

The reflective group's mean $(\mathrm{M}=244.2, \mathrm{SD}=3.68)$ is slightly lower than the control group $(\mathrm{M}=24.5, \mathrm{SD}=3.5)$.

As it is observed in Table 3, the results of independent samples t-test $(\mathrm{t}(45)=-.285, \mathrm{Sig}=0.77)[-2.420,1.82]$ indicates that the difference between the control group and reflective group is not significant; therefore, the second null hypothesis was supported, and it can be assumed that reflectivity does not have any effect on reading comprehension of Iranian EFL learners.

\section{DISCUSSION}

This study revealed that impulsivity and reflectivity are not determining factors in reading comprehension of Iranian 
Table 1. Distribution of scores for reading test based on learning style

\begin{tabular}{|c|c|c|c|c|c|c|}
\hline & \multirow{2}{*}{$\frac{\mathrm{N}}{\text { Statistic }}$} & \multirow{2}{*}{$\begin{array}{c}\text { Standard deviation } \\
\text { Statistic }\end{array}$} & \multicolumn{2}{|c|}{ Skewness } & \multicolumn{2}{|c|}{ Kurtosis } \\
\hline & & & Statistic & Standard error & Statistic & Standard error \\
\hline Nelson test & 72 & 2.64746 & 0.567 & 0.411 & 0.345 & 0.922 \\
\hline Impulsive & 25 & 3.79693 & -0.962 & 0.464 & 0.629 & 0.902 \\
\hline Reflective & 25 & 3.68556 & -0.835 & 0.464 & 0.332 & 0.902 \\
\hline Control & 22 & 3.50170 & -0.659 & 0.491 & -0.169 & 0.953 \\
\hline
\end{tabular}

Table 2. Independent samples t-test; comparison between the control group and impulsive group

\begin{tabular}{|c|c|c|c|c|c|c|}
\hline \multicolumn{7}{|c|}{ t-test for equality of means } \\
\hline \multirow[t]{2}{*}{ t } & \multirow[t]{2}{*}{ df } & \multirow[t]{2}{*}{ Sig. (2-tailed) } & \multirow[t]{2}{*}{ Mean difference } & \multirow[t]{2}{*}{ Standard error difference } & \multicolumn{2}{|c|}{$\begin{array}{l}95 \% \text { confidence interval of } \\
\text { the difference }\end{array}$} \\
\hline & & & & & Lower & Upper \\
\hline-0.093 & 45 & 0.926 & -0.1000 & 1.070 & -2.256 & 2.056 \\
\hline
\end{tabular}

Table 3. Independent samples t-test; the control group vs. the reflective group

\begin{tabular}{|c|c|c|c|c|c|c|}
\hline \multicolumn{7}{|c|}{ t-test for equality of means } \\
\hline \multirow[t]{2}{*}{$\mathbf{t}$} & \multirow[t]{2}{*}{ df } & \multirow[t]{2}{*}{ Sig. (2-tailed) } & \multirow[t]{2}{*}{ Mean difference } & \multirow[t]{2}{*}{ Standard error difference } & \multicolumn{2}{|c|}{$\begin{array}{l}95 \% \text { confidence interval of the } \\
\text { difference }\end{array}$} \\
\hline & & & & & Lower & Upper \\
\hline-0.285 & 45 & 0.777 & -0.300 & 1.0526 & -2.420 & 1.820 \\
\hline
\end{tabular}

EFL learners. In general there is no consensus about the role and effect of learning styles in language classes, although many studies have revealed the effect of learning styles on learning various language skills and sub-skills as mentioned in literature section. For example, Winke (2007) posited that learning styles are the peak of difference between individuals in a language class, but whether this difference has effect on the input-to-intake process requires more research. In line with Winke (2007), we realized that in contrast to studies that have assumed a certain role for learning styles (e.g., Safari \& Rastegar, 2017), learning styles do not affect learning in terms of reading comprehension. Dörnyei and Skehan (2003) also acknowledged this difference, but they raised one pivotal question, "is it possible to distinguish language learners based on their learning styles?" To many educators such a division might seem to be impossible. Consistent with Dörnyei and Skehan (2003), we believe that such a division is unnecessary for the reading skill and personal learning styles, i.e., impulsivity and reflectivity.

Ellis (2005) believes that teachers should use techniques and materials that can be used by various learners with different learning styles, but Wang, Wang and Huang (2008) believe in distinguishing language learners based on their learning styles. Consist with Ellis (2005) we believe that techniques used in language classes should be general. As observed in this study, learning styles do not always affect learning languages. Indeed, Ellis (2005) suggested that instead of thinking about matching language classes based on learners learning styles, language teachers and syllabus designers can design activities that cover the need of various language learners.
Another significant aspect of the issue of learning styles is its relationship with language learning strategies. Oxford (1990) who was among the pioneers who discussed language strategies and the scholar who distinguished these strategies from learning styles (since they were referred to interchangeability at times) believed that learning style is a psychological trait, a subconscious behavior, based on which language learners made conscious decisions such as strategy selection. Therefore, a person who prefers a cognitive strategy such as underlining while reading may have an analytical (field independent) learning style. In Oxford's tradition, one of the most significant influences of any particular learning style was selecting a learning strategy; therefore, by explicit instruction of learning strategies, language learners could be guided in the learning process. Contrary to this notion, Dornyei (2005) asserted that many factors can affect language learners' use of strategies which have no relationship with styles. He used 'affect' as an umbrella term to refer to these features. Motivation attitude and anxiety are among these features.

Finally the researchers noticed a shortcoming regarding the studies that have been conducted on the effect or relationship of learning styles and language learning. Most of these studies have to made use of numerous groups of language learners in their experimental groups. Therefore, and in order to avoid excessive number of groups, they have forgotten to consider some significant variables such as age, gender, social status, religion, etc. All these factors can have a role in determination of language learners' learning styles. At the same time due to research being scant in this area, more attention should be paid to these factors. 
Learners' learning styles and autonomy has also been subject of investigation. Foen (2009), for instance, found out that learning styles, the learning environment as perceived by the learners and the learners experience with technology can affect language learning and learners autonomy. Gültekin and Karababa (2010), found a similar effect among Turkish language learners. In contrast, Reeve and Jang (2006) assumed that language learners' techniques played a more effective role and learners' styles in learning do not have a significant effect.

\section{CONCLUSION}

In an attempt to find out how language learners' learning style may affect reading comprehension, and in order to increase the outcome of language classes, the researchers endeavored to find out if personality learning styles, i.e., impulsivity and reflectivity have any effect on reading comprehension of Iranian EFL learners. It was found that these two learning styles are not determining learning styles with regard to reading comprehension as their effect on reading comprehension of Iranian EFL learners was not statistically significant.

The researchers encountered a number of limitations in the study. This study was conducted by limited number of participants in one language center, though the researchers wished to be able to consider more participants. In addition, a number of confounding variables such as economic and social background of the participants were not taken into account.

Based on the findings of this study there seems to be no need to match the classes based on language learners' learning style (impulsivity vs. reflectivity). Instead of such a rigorous process, teachers can make use of learning materials and teaching techniques that are more suitable for learners with diverse learning preferences.

\section{REFERENCES}

Cohen, A. D. (2003). The learner's side of foreign language learning: Where do styles, strategies, and tasks meet? IRAL, 41(4), 279-292.

Dörnyei, Z., \& Skehan, P. (2003). Individual differences in second language learning. The handbook of second language acquisition, 589-630.

Ellis, R. (2005). The study of second language acquisition. Shanghai: Shanghai Foreign Education Press.

Foen, N.S. (2009). Learning autonomy and some selected correlates among adult distance learners in Malaysia (Published Doctoral Thesis), University Putra Malaysia, Malaysia.
Gilakjani, A. P. (2011). Visual, auditory, kinaesthetic learning styles and their impacts on English language teaching. Journal of Studies in Education, 2(1), 104-113.

Gültekin, İ. \& Karababa, Z.C. (2010). The Relation between the autonomy level and the learning styles of English language learners. Ankara University Turkey. EABR \& ETLC Conference Proceedings Dublin, Ireland.

Hajimohammadi, R., \& Mukundan, J. (2011). Impact of self-correction on extrovert and introvert students in EFL writing progress. English Language Teaching, 4(2), 161.

Han, Z., Park, E. S., \& Combs, C. (2008). Textual enhancement of input: Issues and possibilities. Applied Linguistics, 29(4), 597-618.

Kolb, A. Y., \& Kolb, D. A. (2005). Learning styles and learning spaces: Enhancing experiential learning in higher education. Academy of management learning \& education, 4(2), 193-212.

Lozanov, G. (1979). Suggestology and suggestopedia: theory and practice. United Nations Educational, Scientific, and Cultural Organization.

Littlewood, W. (2002). Foreign and second language learning. Beijing: Foreign Language Teaching and Research Press.

Reeve, J., \& Jang, H. (2006). What teachers say and do to support students' autonomy during a learning activity. Journal of educational psychology, 98(1), 209.

Oxford, R.L. (2001). Language learning styles and strategies. In D. Cohen. Teaching English as A Second or Foreign Language (pp. 211-234) Boston: Heinle \& Heinle Press.

Rastegar, B., \& Safari, F. (2017). Output-Based Instruction, Learning Styles and Vocabulary Learning in the EFL Context of Iran. International Journal of Education and Literacy Studies, 5(2), 101-111.

Reid, J. M. (1995). Learning styles in the ESL/EFL classroom. Heinle \& Heinle Publishers,

Wang, T. I., Wang, K. T., \& Huang, Y. M. (2008). Using a style-based ant colony system for adaptive learning. Expert Systems with applications, 34(4), 2449-2464.

Winke, P. M. (2007). The psychology of the language learner: Individual differences in second language acquisition. Studies in Second Language Acquisition, 29(01), $143-144$

$\mathrm{Xu}, \mathrm{W}$. (2011). Learning styles and their implications in learning and teaching. Theory and Practice in language Studies, 1(4), 413-416.

Zoghi, M. (2012). An instrument for EFL reading anxiety: Inventory construction and preliminary validation. The Journal of ASIA TEFL, 9(1), 31-56. 